\title{
STUDI SIFAT FISIK TANAH PADA KEBUN KARET DAN KELAPA SAWIT DI DESA RASAN KECAMATAN NGABANG KABUPATEN LANDAK
}

\author{
STUDY OF SOIL PHYSIC ON RUBBER AND OIL PALM PLANTATION IN VILLAGE \\ RASAN SUBDISTRICT NGABANG DISTRICT LANDAK
}

\author{
Riduan, Junaidi, dan Rita Hayati \\ Program Studi Ilmu Tanah Fakultas Pertanian Universitas Tanjungpura, Pontianak \\ Jln. Prof. Dr. Hadari Nawawi, Pontianak, 78124, Indonesia.
}

Email : ridwan90@gmail.com

\begin{abstract}
ABSTRAK
Penelitian ini bertujuan untuk membandingkan sifat fisik tanah pada kebun karet dan kelapa sawit di Desa Rasan Kecamatan Ngabang Kabupaten Landak. Titik pengamatan sampel tanah di ambil pada kebun karet dan kelapa sawit dengan kedalaman 0-30 cm dan 30-60 cm. Parameter pengamatan yang digunakan pada penelitian ini terdiri dari karakteristik sifat fisik tanah yaitu warna tanah, struktur tanah, tekstur tanah, bobot isi tanah, kadar air kapasitas lapangan, porositas tanah, permeabilitas tanah, kemantapan agregat tanah, kandungan $\mathrm{C}$-organik, $\mathrm{N}$-total, $\mathrm{C} / \mathrm{N}$ rasio, dan reaksi tanah $(\mathrm{pH})$.

Hasil pengamatan warna tanah di lapangan pada kebun karet dan kelapa sawit diketahui bahwa, terdapat beberapa perbedaan dan persamaan pada setiap titik pengamatan. Struktur tanah kebun karet dengan kedalaman 0-30 $\mathrm{cm}$ dan 30-60 $\mathrm{cm}$ gumpal membulat dan butir (granular) sedangkan pada kebun kelapa sawit dengan kedalaman 0-30 cm dan 30-60 cm struktur tanah yaitu gumpal bersudut. Sementara tekstur tanah pada kebun karet kedalaman 0-30 cm dan $30-60 \mathrm{~cm}$ termaksuk lempung liat berpasir dan lempung berliat sedangkan tekstur tanah pada kebun kelapa sawit dengan kedalaman 0-30 cm dan 30-60 cm termasuk lempung liat berpasir, liat dan lempung berliat.

Kemantapan agregat tanah lebih tinggi pada kebun kelapa sawit dibandingkan dengan kebun karet. Sementara hasil analisis bahan organik pada kebun karet dan kelapa sawit tergolong rendah sampai dengan sangat rendah baik itu pada kedalaman 0-30 cm maupun 30-60 cm, N-total rendah sampai dengan sangat rendah, dan $\mathrm{C} / \mathrm{N}$ rasio rendah serta reaksi tanah $(\mathrm{pH})$ masam sampai sangat masam.
\end{abstract}

Kata kunci : Ultisol, Sifat Fisik Tanah, Karet dan Kelapa Sawit.

\section{ABSTRACT}

This study aimed to compare the physical properties of soil on rubber and oil palm plantation in the village of the District Rasan Ngabang Porcupine District. Observation point soil samples taken at rubber plantations and palm oil to a depth of 0-30 cm and $30-60 \mathrm{~cm}$. Parameter observations used in this study consists of the characteristic physical properties of the soil that is the color of the soil, soil structure, soil texture, bulk density soil, the water content of field capacity, soil porosity, permeability, stability of soil aggregates, content of organic $C$, $N$-total , $C / N$ ratio, and soil reaction $(\mathrm{pH})$.

The results of the t test soil porosity rubber plantations and palm oil at a depth of $0-30 \mathrm{~cm}$ and $30-60 \mathrm{~cm}$ are not significantly different. While the t-test, soil permeability in rubber plantations and palm oil to a depth of $0-30 \mathrm{~cm}$ and $30-60 \mathrm{~cm}$ showed no significant difference.

Soil aggregate stability was higher in oil palm plantations over rubber either the depth of 0 $30 \mathrm{~cm}$ and $30-60 \mathrm{~cm}$. While the results of the analysis of organic materials in the rubber plantations 
and palm oil is low to very low both at a depth of 0-30 cm and 30-60 cm, N-total is low to very low, and $\mathrm{C} / \mathrm{N}$ ratio is low and soil reaction $(\mathrm{pH})$ acid to very acid.

Keywords: Ultisol, Soil Physical Properties, rubber and oil palm.

\section{PENDAHULUAN}

Indonesia memiliki lahan kering masam cukup luas yaitu sekitar 99,6 juta hektar dan tersebar di Kalimantan, Sumatera, Maluku, Papua, Sulawesi, Jawa dan Nusa Tenggara (Subagyo, dkk. 2004). Namun demikian, pemanfaatan lahan ini menghadapi kendala karakteristik tanah yang dapat menghambat pertumbuhan tanaman terutama tanaman tahunan dan pangan bila tidak dikelola dengan baik. Beberapa kendala sifat fisik tanah yang sering dijumpai antara lain adalah kemantapan agregat yang rendah, tanah mudah menjadi padat dan permeabilitas tanah yang lambat.

Tanah ultisol memiliki prospek yang besar untuk di kembangkan menjadi lahan pertanian seperti untuk tanaman karet dan kelapa sawit terutama dalam hubungannya peningkatan pendapatan dan membuka lapangan pekerjaan bagi petani. Tanah ultisol untuk pertumbuhan tanaman karet pada umumnya lebih mempersyaratkan sifat fisik tanah dari pada sifat kimianya hal ini disebakan karena perbaikan sifat kimia untuk syarat tumbuh tanaman karet perlakuan tanah agar sesuai dengan syarat tumbuh tanaman karet dapat dilaksanakan dengan lebih mudah dibandingkan dengan perbaikan sifat fisiknya. Sedangkan pertumbuhan tanaman sawit sangat bergantung dengan sifat fisik tanah dan kimia dalam arti kesuburan tanah. Tanaman sawit tidak bisa tumbuh dengan normal pada keadaan sifat fisik tanah yang kurang baik dan unsur hara yang kurang.

Hingga kini diperkirakan sudah hampir mencapai $300.000 \mathrm{Ha}$ luas lahan perkebunan yang sudah di kelola oleh petani khususnya di wilayah Kecamatan Ngabang diantaranya 22,684 ha sudah di jadikan lahan perkebunan kelapa sawit dari jumlah itu diantaranya 16,336 ha merupakan tanaman yang sudah menghasilkan dengan jumlah produksi 71,114 ton minyak sawit mentah (CPO). Sementara karet tersebar merata di 10 kecamatan, dengan total areal 77,393 ha dan menyerap 30.453 kepala keluarga petani. Perkebunan terluas terdapat di Kecamatan Air Besar dan Sengah
Temila. Namun, produksi karet di Landak baru mencapai 29,728 ton, yang dihasilkan dari 46,208 ha. Soalnya, sebagian kebun masih berupa tanaman muda, dan 5,446 ha lainnya merupakan tanaman tidak produktif yang perlu diremajakan. (Kantor Camat Ngabang Kabupaten Landak, Tahun 2015).

Daerah penelitian terletak di Desa Rasan, Kecamatan Ngabang, Kabupaten Landak dengan luas wilayah 5335,62 Ha. Lokasi penelitian dapat di tempuh dengan menggunakan kendaraan roda empat dan roda dua dengan jarak tempuh selama \pm 1 jam dari kota Ngabang. Secara administratif Desa Rasan memiliki batas-batas sebagai berikut: Sebelah Utara berbatasan dengan Desa Muun, Sebelah Selatan berbatasan dengan Desa Ambarang, Sebelah Timur berbatasan dengan Desa Sengai Keli, dan Sebelah Barat berbatasan dengan Desa Amang.

Penelitian ini bertujuan untuk membandingkan sifat fisik tanah pada kebun karet dan kelapa sawit di Desa Rasan Kecamatan Ngabang Kabupaten Landak.

\section{METODE PENELITIAN}

Penelitian dilaksanakan di perkebunan karet dan kelapa sawit letaknya di wilayah Desa Rasan Kecamatan Ngabang Kabupaten Landak. Kemudian dilanjutkan dengan analisis sifat fisika tanah pada Laboratorium Fisika dan Konservasi Tanah dan Laboratorium Kimia dan Kesuburan Tanah Fakultas Pertanian Universitas Tanjungpura Pontianak. Waktu penelitian kurang lebih tiga bulan terhitung dari tanggal 18 Desember 2015 sampai dengan 11 Maret 2016. Waktu tersebut mencakupi penelitian di lapangan dan analisis di Laboratorium hingga analisis data akhir untuk memperoleh kesimpulan dari hasil penelitian.

Bahan yang digunakan dalam penelitian ini adalah contoh sampel tanah yang diambil pada setiap titik pengamatan di lapangan, yang sudah ditentukan titiknya pada peta titik pengamatan dengan skala 1:250.000 melalui survey langsung di lapangan. Sampel tanah yang diambil untuk dianalisis di laboratorium 
yaitu sampel tanah utuh, sampel tanah agregat utuh dan tanah terganggu yang diperoleh dari lokasi penelitian pada dua vegetasi tanaman yaitu kebun karet dan kebun kelapa sawit dengan kedalaman 0-30 cm dan 30-60 cm di wilayah Desa Rasan serta bahan-bahan kimia yang diperlukan dalam proses analisis sampel tanah di laboratorium.

Peralatan yang di gunakan dalam penelitian ini meliputi cangkul, pisau, parang, meteran, ring sampel, bor tanah, tali rafia, alat tulis-menulis, palu, kantong plastik, kertas label, karet gelang, alat dokumentasi, GPS, timbangan, penggali, potongan papan, buku munsell serta peralatan lain yang mendukung selama pengambilan sampel tanah di lapangan.

Penelitian ini menggunakan metode survey langsung di lapangan dengan melakukan pengamatan dan pengambilan sampel tanah pada kebun karet dan kelapa sawit di Desa Rasan Kecamatan Ngabang Kabupaten Landak dan melakukan wawancara langsung dengan petani mengenai sistem budidaya tanaman karet dan kelapa sawit yang sudah di lakukan. Penelitian di Desa Rasan akan dilaksanakan dalam tiga tahapan yaitu meliputi persiapan penelitian, pengambilan sampel tanah, dan analisis sampel tanah di Laboratorium.

\section{HASIL DAN PEMBAHASAN}

\section{Warna Tanah}

Dari hasil pengamatan warna tanah di lapangan pada kebun karet dan kelapa sawit dapat diketahui bahwa, terdapat beberapa perbedaan dan persamaan warna tanah pada setiap titik pengamatan baik itu pada kedalaman 0-30 cm maupun 30-60 cm. Untuk kedalaman $0-30 \mathrm{~cm}$ pada titik pengamatan kebun karet $\mathrm{K} 1, \mathrm{~K} 3$ dan $\mathrm{K} 8$ terdapat warna tanah yaitu 10YR 6/8 (Kuning Kecoklatan) dan pada titik pengamatan $\mathrm{K} 2, \mathrm{~K} 4, \mathrm{~K} 5, \mathrm{~K} 6$ serta K7 warna tanah 10YR 5/8 (Coklat Kekuningan) sedangkan pada titik pengamatan kebun kelapa sawit pada kedalaman 0-30 cm diketahui S1, S2, S3, dan S5 terdapat warna tanah yaitu 10YR 6/8 (Kuning Kecoklatan) dan pada titik pengamatan S4 dan S6 warna tanah 10YR 5/8 (Coklat Kekuningan) sementara pada titik pengamatan S7 warna tanah 10YR 7/6 (Kuning) dan S8 dengan warna tanah 7,5YR 6/8 (Kuning Kemerahaan).
Sedangkan untuk kedalaman $30-60 \mathrm{~cm}$ pada titik pengamatan $\mathrm{K} 1, \mathrm{~K} 2, \mathrm{~K} 3, \mathrm{~K} 4, \mathrm{~K} 5$, dan $\mathrm{K} 7$ diketahui warna tanah pada kebun karet yaitu 10YR 6/8 (Kuning Kecoklatan) sementara pada titik pengamatan K6 dan K8 warna tanah 10YR 7/8 (Kuning). Pengamatan warna tanah pada kebun kelapa sawit dengan kedalaman 30-60 cm diketahui S1, S2, S3, S5, dan S6 memiliki warna tanah yaitu 10YR 7/8 (Kuning) sementara pada titik pengamatan S4 warna tanah 10YR 6/8 (Kuning Kecoklatan), S7 warna tanah 10YR 6/6 (Kuning Kecoklatan) dan S8 warna tanah 5YR 5/8 (Merah Kekuningan).

Menurut (Foth, 1998), bahan organik merupakan sebuah bahan utama pewarnaan tanah yang tergantung pada keadaan alaminya, jumlah dan penyebaran dalam profil tanah tersebut. Warna tanah cenderung beragam menurut posisi topografi. Hanafiah (2005), juga menambahkan, warna terang kerap kali merupakan hasil intensifnya pelindian besi dari tanah, yang umumnya bersamaan dengan hilangnya berbagai unsur hara, sehingga tanah berwarna terang sering di kaitkan dengan rendahnya produktivitas. Hal ini disebabkan makin tinggi kandungan bahan organiknya, maka warna tanah akan semakin gelap. Sebaliknya, semakin rendah kandungan bahan organiknya warna tanah akan tampak lebih terang sehingga dapat berpengaruh terhadap warna tanah pada setiap lapisan tanah.

\section{Bentuk Struktur Tanah}

Dari hasil pengamatan struktur tanah pada kebun karet di ketahui bahwa, pada titik pengamatan $\mathrm{K} 1, \mathrm{~K} 2, \mathrm{~K} 8$ pada kedalaman 0-30 $\mathrm{cm}$ memiliki bentuk struktur tanah sama yaitu gumpal membulat. Struktur tanah gumpal membulat yang berarti bentuk struktur tanah tersebut memiliki sumbu vertikal dan sumbu horizontal sama dan sisi-sisi nya membentuk sudut membulat biasanya bentuk struktur tanah ini terdapat pada lapisan tanah horison B. Sedangkan pada titik pengamatan K4-K7 memiliki bentuk struktur tanah butir (Granular) yaitu struktur tanah yang berbentuk granul, bulat dan porous, struktur ini terdapat pada horison A. Sedangkan pada kebun kelapa sawit untuk pengamatan S1-S8 dengan kedalaman 0$30 \mathrm{~cm}$ memiliki bentuk struktur tanah yang sama yaitu gumpal bersudut dengan sumbu vertikal sama dengan sumbu horizontal dan 
sisi-sisi membentuk sudut tajam biasanya ditemukan pada horizon B di daerah iklim basah.

Pada kedalaman 30-60 $\mathrm{cm}$ untuk titik pengamatan $\mathrm{K} 1, \mathrm{~K} 2$, $\mathrm{K} 5$, dan $\mathrm{K} 8$ pada kebun karet memiliki bentuk struktur tanah yang sama yaitu gumpal membulat. Sedangkan pada titik pengamatan $\mathrm{K} 3, \mathrm{~K} 4, \mathrm{~K} 6$, dan $\mathrm{K} 7$ dengan kedalaman 30-60 cm memiliki bentuk struktur tanah yang sama yaitu butir (Granular) dan untuk pengamatan pada kebun kelapa sawit pada kedalaman 30-60 cm diketahui bahwa pada titik pengamatan S1-S8 memiliki bentuk struktur tanah yang sama yaitu gumpal bersudut sumbu vertikal sama dengan sumbu horizontal dan sisi-sisi membentuk sudut tajam. Tingkat perkembangan struktur tanah ditentukan berdasar atas kemantapan atau ketahanan bentuk struktur tanah tersebut terhadap tekanan. Tanah dengan struktur baik (granuler, remah) mempunyai tata udara yang baik, unsur-unsur hara lebih mudah tersedia dan mudah diolah. Struktur tanah yang baik adalah yang bentuknya membulat sehingga tidak dapat saling bersinggungan dengan rapat.

\section{Tekstur Tanah}

Dari data hasil analisis tekstur tanah dapat dibuat suatu perbandingan dengan diagram batang untuk nilai rerata tekstur tanah pada kebun karet dan kelapa sawit di bawah ini.

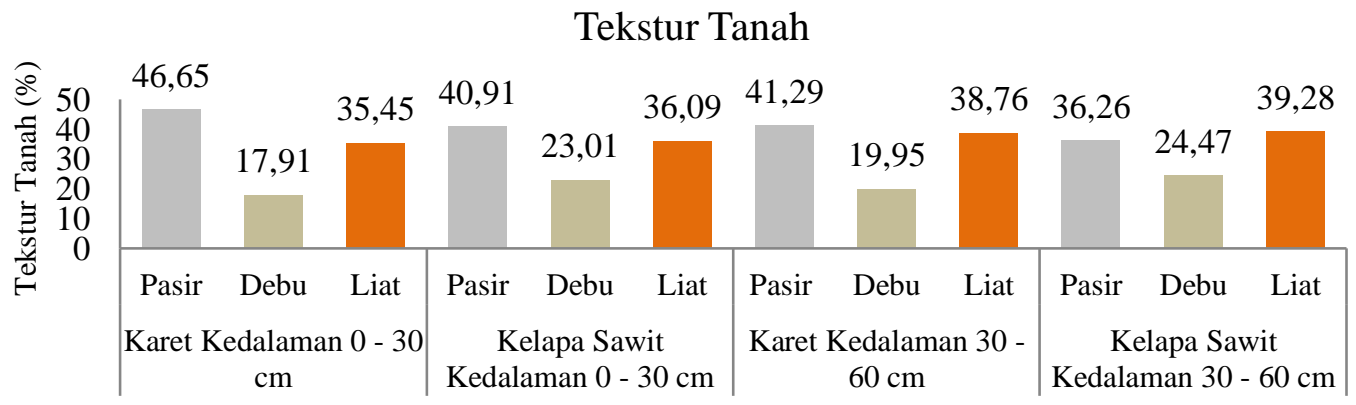

Gambar 1. Nilai Rerata Tekstur Tanah Kebun Karet dan Kelapa Sawit

Dari hasil analisis tekstur tanah dapat dilihat bahwa, tekstur tanah pada kebun karet dengan kedalaman $0-30 \mathrm{~cm}$ memiliki kandungan pasir $(46,65 \%)$ lebih besar dibandingkan dengan liat $(35,45 \%)$ dan liat lebih besar dibandingkan dengan debu $(17,91$ $\%)$ sedangkan tekstur tanah pada kebun kelapa sawit dengan kedalaman 0-30 cm memiliki kandungan pasir $(40,91 \%)$ lebih besar di bandingkan liat $(36,09 \%)$ dan liat lebih besar dari debu $(23,01 \%)$. Tanah yang mempunyai kandungan pasir yang cukup tinggi mempunyai pori-pori makro lebih banyak dari pada pori-pori mikro, hal ini menyebabkan terjadinya aerasi yang baik, daya hantar airnya baik namun kemampuan menyimpan unsur hara rendah dan partikel pasir dapat saling berikatan lebih kuat sehingga dapat menyebabkan bahan organiknya sedang dan membuat kemantapan agregat yang lebih stabil (Djokomoeljanto, 1987).
Untuk kedalaman 30-60 cm pada kebun karet nilai rata-rata tekstur tanah fraksi pasir $(41,29 \%)$ lebih besar dibandingkan liat $(38,76$ $\%)$ dan liat lebih besar dari debu $(19,95 \%)$ sedangkan untuk tekstur tanah pada kebun kelapa sawit dengan kedalaman 30-60 cm dimana nilai fraksi liat $(39,28 \%)$ lebih besar dibandingkan pasir $(36,26 \%)$ dan pasir lebih besar dari debu $(24,47 \%)$. Berdasarkan atas perbandingan banyaknya butiran-butiran fraksi pasir, debu dan liat, maka bentuk struktur tanah pada kebun karet dan kelapa sawit memiliki kriteria tekstur tanah lempung liat berpasir, lempung berliat dan liat.

\section{Bobot Isi Tanah (gram/ $\left.\mathrm{cm}^{3}\right)$}

Hasil analisis uji t pada kebun karet dan kelapa sawit menunjukan bahwa nilai bobot isi tanah berbeda nyata pada kedalaman 0-30 cm sedangkan pada kedalaman 30-60 cm 
menunjukan bahwa nilai bobot isi tanah tidak berbeda nyata.

Dari data hasil analisis maka dapat dibuat suatu perbandingan diagram batang untuk nilai rerata bobot isi tanah pada kebun karet dan kelapa sawit di bawah ini.

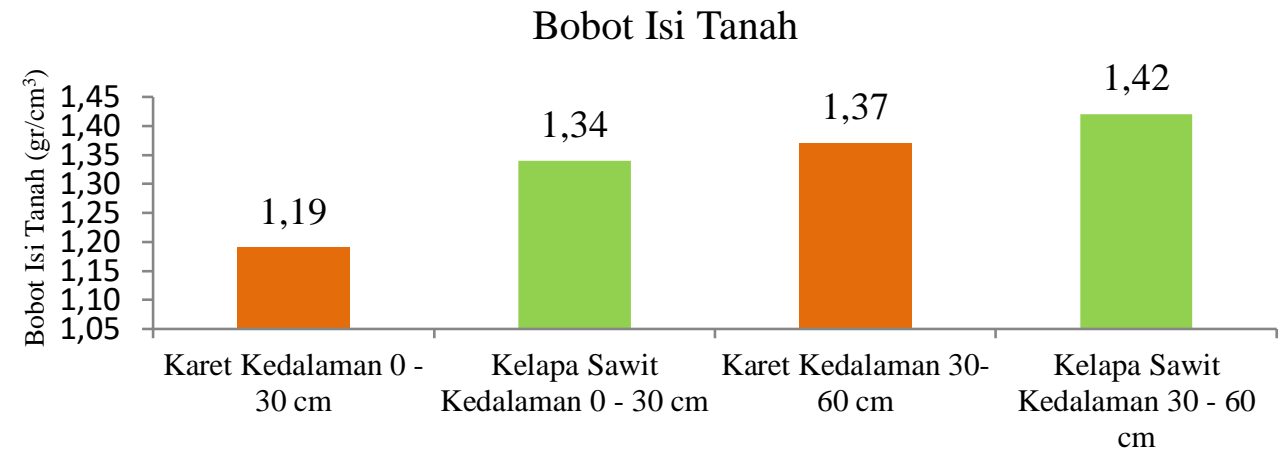

Gambar 2. Nilai Rerata Bobot Isi Tanah Kebun Karet dan Kelapa Sawit

Nilai rerata bobot isi tanah diatas menunjukan bahwa kebun kelapa sawit mempunyai bobot isi tanah lebih tinggi dibandingkan dengan kebun karet baik pada kedalaman 0-30 cm maupun pada kedalaman $30-60 \mathrm{~cm}$. Hal ini disebabkan karena nilai tekstur tanah fraksi liat lebih tinggi pada kebun kelapa sawit dibandingkan dengan tekstur tanah fraksi liat pada kebun karet sehingga dapat mengakibatkan proses pemadatan tanah lebih tinggi pada kebun kelapa sawit.

Berdasarkan nilai rerata kandungan bobot isi tanah pada kebun karet dan kelapa sawit, nilai bobot isi tanah mengalami peningkatan seiring dengan peningkatan kedalaman tanah dari kedalaman tanah 0-30 $\mathrm{cm}$ sampai dengan 30-60 $\mathrm{cm}$. Hal ini disebabkan dengan semakin meningkatnya kedalaman tanah maka kandungan bahan organik akan semakin rendah sehingga membuat proses pemadatan tanah akan menjadi lebih mudah sehingga menyebabkan sifat fisik bobot isi tanah akan semakin tinggi.
Dengan demikian apabila sifat fisik bobot isi tanah semakin tinggi maka semakin sulit untuk meneruskan air ke dalam tanah sehingga berpengaruh juga pada penyerapan air pada akar tanaman. Dengan meningkatnya nilai bobot isi tanah maka dapat menyebabkan ruang pori tanah menurun sehingga dapat berpengaruh terhadap aerasi tanah akan terhambat demikian juga dengan peredaran air tanah akan terhambat.

\section{Kadar Air Kapasitas Lapangan (\% Vol)}

Hasil perhitungan uji t pada data hasil analisis kadar air kapasitas lapangan pada kebun karet dan kelapa sawit menunjukan bahwa pada kedalaman $0-30 \mathrm{~cm}$ berbeda nyata sedangkan pada kedalaman 30-60 cm tidak berbeda nyata.

Dari data hasil analisis maka dapat dibuat suatu perbandingan diagram batang untuk nilai rerata kadar air kapasitas lapangan pada kebun karet dan kelapa sawit dibawah ini. 


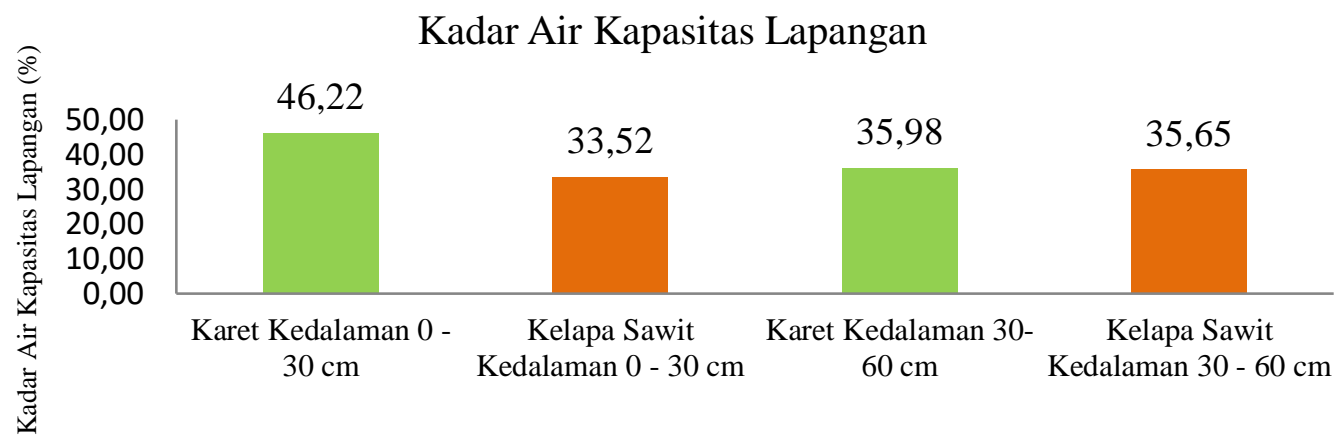

Gambar 3. Nilai Rerata Kadar Air Kapasitas Lapangan Kebun Karet dan Kelapa Sawit

Nilai rerata kadar air kapasitas lapangan di atas menunjukan bahwa kebun karet memiliki kadar air kapasitas lapangan lebih tinggi dibandingkan dengan kebun kelapa sawit baik itu pada kedalaman 0-30 cm maupun 30-60 cm. Jika dilihat dari hasil analisis tekstur tanah pada kebun karet dan kelapa sawit baik kedalaman 0-30 cm maupun 30-60 cm menunjukan bahwa nilai tekstur tanah fraksi pasir lebih tinggi pada kebun karet dibandingkan dengan tekstur tanah fraksi pasir pada kebun kelapa sawit.

Menurut Hardjowigeno (2003), bahwa tanah-tanah bertekstur kasar mempunyai daya menahan air lebih kecil daripada tanah bertekstur halus. Hal ini diakibatkan karena tekstur tanah pada lapisan ini juga mengandung liat yang cukup banyak, sehingga kemampuan menyimpan air oleh tanah kuat. Hal ini sesuai dengan pendapat (Pairunan, dkk. 1985) yang menyatakan bahwa liat dapat menyimpan air lebih banyak dari pasir, karena liat mempunyai luas permukaan yang luas yang dapat diselimuti air.

\section{Porositas Tanah (\%)}

Hasil uji t menunjukan bahwa porositas tanah pada kebun karet dan kelapa sawit pada kedalaman 0-30 cm maupun pada kedalaman 30-60 cm tidak berbeda nyata. Dari data hasil analisis maka dapat dibuat suatu perbandingan diagram batang untuk nilai rerata porositas tanah pada kebun karet dan kelapa sawit di bawah ini.

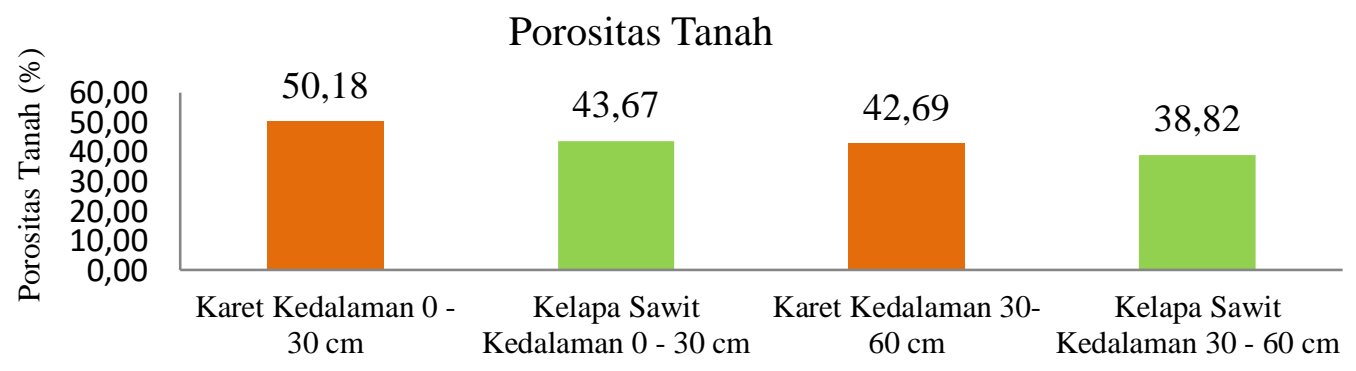

Gambar 4. Nilai Rerata Porositas Tanah Kebun Karet dan Kelapa Sawit

Jika dilihat dari nilai rerata porositas tanah pada diagram batang diatas menunjukan bahwa porositas tanah lebih besar terjadi pada kebun karet dibandingkan dengan kebun kelapa sawit baik itu pada kedalaman 0-30 cm maupun 30-60 cm. Hal ini dikarenakan nilai bobot isi tanah pada kebun karet baik itu pada kedalaman 0-30 $\mathrm{cm}$ maupun 30-60 $\mathrm{cm}$ rendah dan nilai kadar air kapasitas lapang pada kebun karet lebih tinggi baik itu pada kedalaman 0-30 $\mathrm{cm}$ maupun 30-60 $\mathrm{cm}$. Seiring dengan peningkatan kedalaman lapisan tanah pada kedua kebun tersebut sehingga mengalami penurunan nilai porositas tanah baik itu kedalaman 0-30 cm maupun 30-60 cm.

Selain faktor nilai bobot isi tanah dan kadar air kapasitas lapangan, kandungan bahan organik tanah juga dapat mempengaruhi nilai porositas tanah semakin tinggi kandungan bahan organik di dalam tanah maka nilai porositas semakin tinggi. Bahan organik berpengaruh karena mempengaruhi kandungan 
pada lapisan, nilai porositasnya rendah karena lapisan ini terjadi proses pencucian bahanbahan organik sehingga bahan organiknya semakin besar turun ke lapisan bawahnya. Hal ini sesuai dengan pendapat (Foth, 1998), bahwa lapisan kandungan bahan organik suatu lapisan rendah maka nilai porositasnya rendah. Porositas juga dapat di pengaruhi oleh keadaan struktur tanah. Struktur tanah yang kasar biasanya sulit untuk menahan air sehingga dapat menyebabkan aliran air dalam tanah semakin porus.

\section{Permeabilitas Tanah (cm/jam)}

Hasil perhitungan uji $\mathrm{t}$ menunjukan bahwa permeabilitas tanah pada kebun karet dan kelapa sawit pada kedalaman 0-30 cm maupun 30-60 $\mathrm{cm}$ tidak berbeda nyata.

Dari data hasil analisis permeabilitas tanah maka dapat di buat suatu perbandingan dengan diagram batang untuk nilai rerata permeabilitas tanah pada kebun karet dan kelapa sawit dibawah ini.

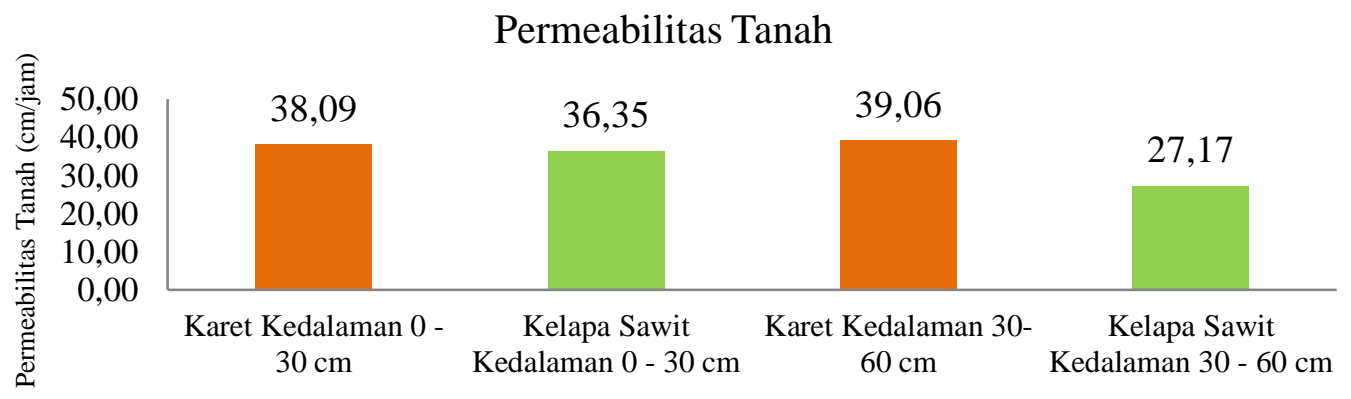

Gambar 5. Nilai Rerata Permeabilitas Tanah Kebun Karet dan Kelapa Sawit

Dilihat dari diagram batang rerata permeabilitas tanah pada kebun karet dan kelapa sawit menunjukan bahwa pada kebun karet mempunyai nilai permeabilitas tanah lebih tinggi dibandingkan dengan nilai permeabilitas tanah pada kebun kelapa sawit baik itu kedalaman 0-30 cm maupun 30-60 cm. Hal ini disebabkan pada kebun karet mempunyai tekstur tanah fraksi pasir lebih tinggi baik itu pada kedalaman 0-30 cm maupun 30-60 cm. Tekstur tanah sangat mempengaruhi permeabilitas tanah. Hal ini dikarenakan permeabilitas itu sendiri adalah melewati tekstur tanah dengan demikian apabila tanah yang bertekstur fraksi pasir lebih tinggi maka akan mudah melewatkan air dalam tanah.

Selain tekstur tanah struktur tanah juga dapat mempengaruhi permeabilitas tanah.
Semakin banyak ruang antar struktur, maka semakin cepat juga proses permeabilitas dalam tanah berjalan. Selain itu porositas tanah juga sangat berpengaruh terhadap nilai permeabilitas tanah. Hal ini sesuai dengan pendapat (Hanafiah, 2005) yang menyatakan bahwa porositas atau ruang pori adalah rongga antar tanah yang biasanya diisi air atau udara. Pori sangat menentukan sekali dalam permeabilitas tanah, semakin besar pori dalam tanah tersebut, maka semakin cepat pula permeabilitas tanah tersebut.

\section{Kemantapan Agregat Tanah}

Dari data hasil analisis kemantapan agregat tanah maka dapat di buat suatu perbandingan dengan diagram batang untuk nilai rerata kemantapan agregat tanah pada kebun karet dan kelapa sawit dibawah. 


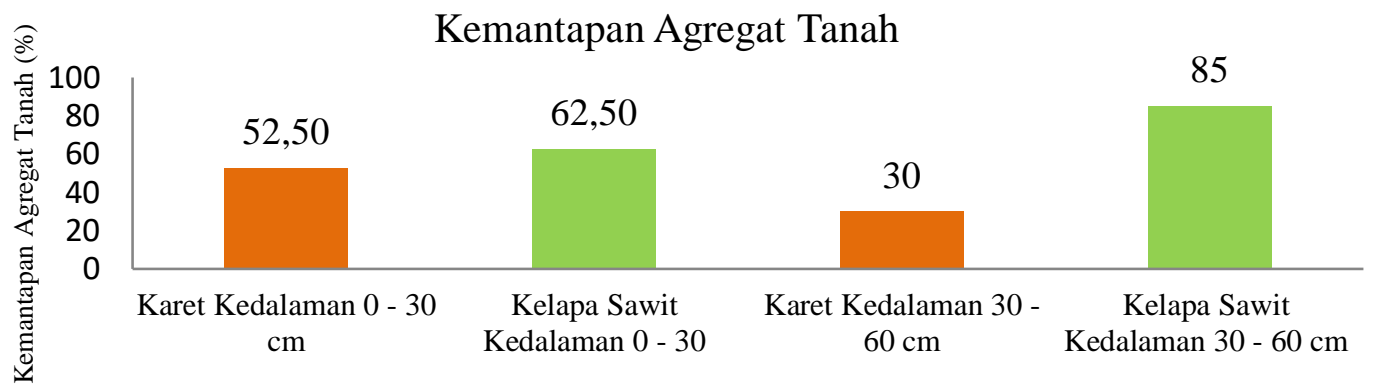

\section{Gambar 6. Nilai Rerata Kemantapan Agregat Tanah Kebun Karet dan Kelapa Sawit}

Agregat tanah merupakan kumpulan partikel-partikel tanah yang terbentuk secara alami, dimana gaya antar partikel lebih kuat dari gaya diantara agregat-agregat tanah yang berdekatan. Berdasarkan nilai rerata kemantapan agregat tanah di atas menunjukan bahwa nilai rata-rata kemantapan agregat tanah lebih tinggi pada kebun kelapa sawit dibandingkan dengan kebun karet baik itu pda kedalaman 0-30 cm maupun 30-60 cm. Hal ini disebabkan karena tekstur tanah fraksi liat lebih tinggi pada kebun kelapa sawit baik itu kedalaman $0-30 \mathrm{~cm}$ maupun 30-60 $\mathrm{cm}$ dibandingkan dengan fraksi liat pada kebun karet.

Selain itu juga nilai bobot isi tanah pada kebun kelapa sawit lebih tinggi dibandingkan dengan kebun karet baik itu pada kedalaman 0$30 \mathrm{~cm}$ maupun 30-60 $\mathrm{cm}$, hal ini dapat berpengaruh terhadap kualitas agregat tanah akan lebih baik pada kebun kelapa sawit dibandingkan dengan kebun karet. Dilihat dari hasil analisis bahan organik tanah pada kebun kelapa sawit dengan kedalaman 30-60 cm menunjukan bahwa nilai bahan organik tanah sangat rendah. Rendahnya kandungan bahan organik tanah dapat membuat tanah semakin padat.

\section{Kandungan Bahan Organik (\%)}

Hasil analisis terhadap kandungan bahan organik tanah pada kebun karet dan kelapa sawit dapat dilihat pada Tabel 1 di bawah ini.

Tabel 1. Nilai Rerata Hasil Analisis Terhadap Kandungan Bahan Organik Tanah Pada Kebun Karet dan Kelapa Sawit

\begin{tabular}{|c|c|c|c|c|c|}
\hline \multirow[b]{2}{*}{ Titik Pengamatan } & \multirow[b]{2}{*}{$\begin{array}{l}\text { Kedalaman } \\
\text { Tanah }(\mathrm{cm})\end{array}$} & \multicolumn{4}{|c|}{ Bahan Organik Tanah (\%) } \\
\hline & & Karet & Harkat & $\begin{array}{c}\text { Kelapa } \\
\text { Sawit }\end{array}$ & Harkat \\
\hline $1-4$ & & 1,24 & Rendah & 1,36 & Rendah \\
\hline $5-8$ & $0-30$ & 1,14 & Rendah & 1,09 & Rendah \\
\hline Jumlah & & 2,38 & & 2,45 & \\
\hline Rata-rata & & 1,19 & & 1,23 & \\
\hline $1-4$ & $30-60$ & 0,86 & Sangat Rendah & 0,50 & Sangat Rendah \\
\hline $5-8$ & $30-00$ & 0,59 & Sangat Rendah & 0,86 & Sangat Rendah \\
\hline Jumlah & & 1,45 & & 1,36 & \\
\hline Rata-rata & & 0,73 & & 0,68 & \\
\hline
\end{tabular}

Sumber : Analisis Laboratorium Kimia dan Kesuburan Tanah 2015

Berdasarkan hasil analisis bahan organik tanah pada Tabel 1 diatas menunjukkan bahwa kebun kelapa sawit mempunyai persentase kandungan bahan organik lebih tinggi dibandingkan kebun karet pada kedalaman 0$30 \mathrm{~cm}$ dengan harkat bahan organik tanah tergolong rendah. Sedangkan pada kedalaman 30-60 $\mathrm{cm}$ persentase kandungan bahan organik justru lebih besar pada kebun karet dibandingkan kebun kelapa sawit dengan harkat bahan organik tanah tergolong sangat rendah. Kandungan C-organik dan bahan organik berkisar sangat rendah sampai rendah. Hal ini menunjukkan bahwa dari sudut pandang kimia tanah, tanah-tanah lokasi penelitian kurang subur. 
Di samping itu, sebagian besar bahan organik yang terdapat di lokasi penelitian mempunyai tingkat dekomposisi yang sangat lanjut, yang ditunjukkan dengan nilai nisbah $\mathrm{C} / \mathrm{N}$ rasio tanah yang sangat rendah. Dilihat dari data curah hujan daerah penelitian tergolong daerah yang memiliki curah hujan sangat tinggi sehingga akan berpengaruh juga terhadap daya tahan tanah akan benturan butiran air hujan. Curah hujan yang relatif tinggi sehingga mengakibatkan terjadinya pencucian bahan organik dan unsur hara di dalam tanah oleh air.

\section{J. N - Total (\%)}

Hasil analisis $\mathrm{N}$-total pada kebun karet dan kelapa sawit dapat dilihat pada Tabel 2 di bawah ini.

Tabel 2. Nilai Rerata Terhadap Hasil Analisis N - Total Pada KebunKaret dan Kelapa Sawit

\begin{tabular}{cccccc}
\hline \multirow{2}{*}{ Titik Pengamatan } & Kedalaman & \multicolumn{4}{c}{$\mathrm{N}-$ Total Tanah $(\%)$} \\
& Tanah $(\mathrm{cm})$ & Karet & Harkat & Kelapa Sawit & Harkat \\
\hline $1-4$ & \multirow{2}{*}{$0-30$} & 0,11 & Rendah & 0,11 & Rendah \\
$5-8$ & & 0,01 & Sangat Rendah & 0,09 & Sangat Rendah \\
Jumlah & & 0,12 & & 0,20 & \\
Rata-rata & & 0,06 & & 0,10 & \\
\hline $1-4$ & \multirow{2}{*}{$30-60$} & 0,08 & Sangat Rendah & 0,04 & Sangat Rendah \\
$5-8$ & & 0,05 & Sangat Rendah & 0,07 & Sangat Rendah \\
Jumlah & & 0,13 & & 0,11 & \\
Rata-rata & & 0,07 & & 0,06 & \\
\hline
\end{tabular}

Sumber : Analisis Laboratorium Kimia dan Kesuburan Tanah 2015

Berdasarkan hasil analisis N-total pada kebun kelapa sawit menunjukan bahwa nilai $\mathrm{N}$-total tanah lebih tinggi dibandingkan dengan kebun karet pada kedalaman 0-30 cm dengan harkat rendah sampai dengan sangat rendah. Hal ini disebabkan pada kebun kelapa sawit mempunyai kandungan bahan organik lebih tinggi dibandingkan dengan kebun karet pada kedalaman 0-30 $\mathrm{cm}$. Sedangkan pada kedalaman 30-60 cm kandungan N-total tanah justru besar pada kebun karet dibandingkan dengan kebun kelapa sawit dengan harkat rendah sampai dengan sangat rendah.
Salah satu faktor yang mempengaruhi nilai N-Total yaitu bahan organik, apabila bahan organiknya tinggi maka nilai $\mathrm{N}$-Total juga tinggi, begitu pula sebaliknya sehingga apabila peningkatan kadar bahan organik terjadi maka $\mathrm{N}$ dalam tanah juga akan meningkat. Dari hasil analisis $\mathrm{N}$ - total pada kedua kebun menunjukan bahwa $\mathrm{N}$ - total tanah sangat rendah sampai dengan rendah.

\section{C/N Rasio}

Dari hasil analisis $\mathrm{C} / \mathrm{N}$ rasio tanah pada kebun karet dan kelapa sawit dapat dilihat pada Tabel 3 dibawah ini.

Tabel 3. Nilai Rerata Terhadap Hasil Analisis C/N Rasio Tanah Kebun Karet dan Kelapa Sawit

\begin{tabular}{cccccc}
\hline \multirow{2}{*}{ Titik Pengamatan } & Kedalaman & \multicolumn{4}{c}{ C/N Rasio Tanah } \\
& Tanah $(\mathrm{cm})$ & Karet & Harkat & Kelapa Sawit & Harkat \\
\hline $1-4$ & \multirow{2}{*}{$0-30$} & 6,55 & Rendah & 7,18 & Rendah \\
$5-8$ & & 6,60 & Rendah & 7,00 & Rendah \\
Jumlah & & 13,15 & & 14,18 & \\
Rata-rata & & 6,58 & & 7,09 & \\
\hline $1-4$ & \multirow{2}{*}{$30-60$} & 6,25 & Rendah & 7,25 & Rendah \\
$5-8$ & & 6,80 & Rendah & 7,14 & Rendah \\
Jumlah & & 13,05 & & 14,39 & \\
Rata-rata & & 6,53 & & 7,20 & \\
\hline
\end{tabular}

Sumber : Analisis Laboratorium Kimia dan Kesuburan Tanah 2015 
Dari hasil analisis $\mathrm{C} / \mathrm{N}$ rasio tanah menunjukan bahwa kebun kelapa sawit memiliki nilai $\mathrm{C} / \mathrm{N}$ rasio lebih tinggi dibandingkan dengan $\mathrm{C} / \mathrm{N}$ rasio tanah pada kebun karet baik itu pada kedalaman $0-30 \mathrm{~cm}$ maupun 30-60 $\mathrm{cm}$ dengan harkat rendah. Besarnya nilai $\mathrm{C} / \mathrm{N}$ rasio tergantung dari jenis sampah yang terdapat di dalam tanah. Jika $\mathrm{C} / \mathrm{N}$ rasio tinggi, aktivitas mikroorganisme akan berkurang. Selain itu diperlukan beberapa siklus mikroorganisme untuk menyelesaikan degradasi bahan kompos sehingga waktu pengomposan akan lebih lama dan kompos yang dihasilkan akan bermutu rendah.

Jika rasio $\mathrm{C} / \mathrm{N}$ terlalu rendah kelebihan nitrogen (N) yang tidak dipakai oleh mikroorganisme tidak dapat diasimilasi dan akan hilang memlaui volatisasi sebagai ammonia atau terdenitrifikasi. Nilai analisis
$\mathrm{C} / \mathrm{N}$ rasio tanah pada kedua kebun menunjukan bahwa bahan organik yang berada di dalam tanah sudah melapuk sempurna sehingga sudah bias di serap oleh tanaman. $\mathrm{C} / \mathrm{N}$ rasio tanah umumnya sekitar 10-12. Sedangkan untuk masa kritis $\mathrm{C} / \mathrm{N}$ rasio tanah berkisar antara 2530 ke atas. Apabila bahan organik memiliki $\mathrm{C} / \mathrm{N}$ rasio mendekati $\mathrm{C} / \mathrm{N}$ rasio tanah, maka bahan tersebut dapat diserap atau digunakan tanaman. Hal ini sesuai dengan pendapat (Djuarnani, dkk. 1996) bahan organik yang memiliki $\mathrm{C} / \mathrm{N}$ rasio sama dengan $\mathrm{C} / \mathrm{N}$ rasio tanah memungkinkan bahan tersebut dapat diserap oleh tanaman.

\section{Reaksi Tanah (pH)}

Hasil analisis $\mathrm{pH}$ tanah pada kebun karet dan kelapa sawit dapat di lihat pada Tabel 4 di bawah ini.

Tabel 4. Nilai Rerata Terhadap Hasil Analisis pH Tanah Pada Kebun Karet dan Kelapa Sawit

\begin{tabular}{cccccc}
\hline Titik Pengamatan & $\begin{array}{c}\text { Kedalaman } \\
\text { Tanah }(\mathrm{cm})\end{array}$ & Karet & Harkat & $\begin{array}{c}\text { pH Tanah } \\
\text { Kelapa Sawit }\end{array}$ & Harkat \\
\hline $1-4$ & \multirow{2}{*}{$0-30$} & 4,54 & Masam & 4,33 & Sangat Masam \\
$5-8$ & & 4,48 & Sangat Masam & 4,42 & Sangat Masam \\
Jumlah & & 9,02 & & 8,75 & \\
Rata-rata & & 4,51 & & 4,38 & \\
\hline $1-4$ & \multirow{2}{*}{$30-60$} & 4,56 & Masam & 4,32 & Sangat Masam \\
$5-8$ & & 4,61 & Masam & 4,44 & Sangat Masam \\
Jumlah & & 9,17 & & 8,76 & \\
Rata-rata & & 4,59 & & 4,38 & \\
& & & & &
\end{tabular}

\section{Sumber : Analisis Laboratorium Kimia dan Kesuburan Tanah 2015}

Dari hasil analisis $\mathrm{pH}$ tanah di laboratorium kimia dan kesuburan tanah kebun karet menunjukan bahwa $\mathrm{pH}$ tanah tertinggi dibandingkan dengan $\mathrm{pH}$ tanah kebun kelapa sawit baik itu pada kedalaman $0-30 \mathrm{~cm}$ maupun 30-60 cm. Hasil analisis $\mathrm{pH}$ tanah menunjukan bahwa kedua kebun memiliki harkat $\mathrm{pH}$ tanah dari yang masam sampai dengan sangat masam. Hal ini disebabkan tanah yang bersifat masam kurangnya kation kalsium, Magnesium, Kalium dan Natrium di dalam tanah sehingga unsur-unsur tersebut terbawa oleh aliran air kelapisan tanah yang lebih bawah atau hilang terserap oleh tanaman. Sedangkan tanah masam juga dapat dikarenakan banyaknya kandungan $\mathrm{Fe}$ dan $\mathrm{Al}$ di dalam tanah.
Sedangkan $\mathrm{pH}$ tanah dengan harkat sangat masam biasanya dipengaruhi oleh tingginya kandungan aluminium atau blerang di dalam tanah. Sehingga pengaruh terbesar yang umum dari $\mathrm{pH}$ tanah terhadap pertumbuhan tanaman adalah berpengaruh terhadap ketersedian unsur hara di dalam tanah. Seperti ketersediaan N, P, K, Ca, Mg dan unsur mikro serta kelarutan unsur yang beracun seperti Al dan Mn. Disamping ini juga mempengaruhi kehidupan jasad mikro dalam tanah.

\section{SIMPULAN}

1. Hasil analisis tekstur tanah pada kebun karet komposisi kandungan fraksi pasir lebih besar dibandingkan dengan fraksi liat, yang terendah fraksi debu. Sedangkan 
tekstur tanah pada kebun kelapa sawit kandungan fraksi pasir lebih besar dibandingkan dengan fraksi liat dan yang terendah adalah fraksi debu.

2. Hasil analisis sifat fisika tanah menunjukan nilai rata-rata bobot isi tanah pada kebun karet lebih rendah dibandingkan dengan nilai rata-rata bobot isi tanah pada kebun kelapa sawit baik itu kedalaman 0-30 cm maupun 30-60 cm. Sedangkan kadar air kapasitas lapangan lebih tinggi pada kebun karet dibandingkan dengan kebun kelapa sawit baik itu kedalaman 0-30 cm maupun $30-60 \mathrm{~cm}$ dan nilai porositas tanah lebih tinggi pada kebun karet dibandingkan dengan kebun kelapa sawit baik itu pada kedalaman 0-30 cm maupun 30-60 cm serta nilai permeabilitas tanah lebih tinggi pada kebun karet dibandingkan dengan kebun kelapa sawit baik itu pada kedalaman 0-30 cm maupun 30-60 cm.

3. Dari hasil analisis menunjukan bahwa kedua kebun memiliki nilai $\mathrm{pH}$ tanah yang tergolong masam sampai dengan sangat masam. Sedangkan untuk $\mathrm{C} / \mathrm{N}$ rasio tanah pada kedua kebun termaksud rendah serta nilai $\mathrm{N}$-total tanah tergolong rendah sampai dengan sangat rendah dan kandungan bahan organik tanah pada kebun karet termaksut rendah sedangkan pada kebun kelapa sawit sangat rendah.

4. Dari hasil analisis uji t terhadap bobot isi tanah pada kebun karet dan kebun kelapa sawit pada kedalaman 0-30 cm berbeda nyata sedangkan kedalaman 30-60 cm tidak berbeda nyata. Sementara hasil uji $\mathrm{t}$ terhadap kadar air kapasitas lapangan pada kebun karet dan kelapa sawit dengan kedalaman $0-30 \mathrm{~cm}$ berbeda nyata sedangkan kedalaman $30-60 \mathrm{~cm}$ tidak berbeda nyata. Hasil analisis uji $t$ terhadap porositas tanah pada kebun karet dan kelapa sawit dengan kedalaman 0-30 cm maupun 30-60 $\mathrm{cm}$ tidak berbeda nyata dan hasil analisis uji t terhadap permeabilitas tanah pada kedalaman 0-30 $\mathrm{cm}$ maupun $30-60 \mathrm{~cm}$ tidak berbeda nyata.

\section{DAFTAR PUSTAKA}

Djuarnani, N. Kristina dan S.S. Budi. 1996. Cara Cepat Membuat Kompos. Depok: Agro Media Pustaka.

Djokomoeljanto, A. 1987. Hubungan Beberapa Sifat Fisik, Kimia dan Aktivitas Mikroorganisme Tanah Dengan Kemantapan Agregat Tanah. Bogor (IPB).

Foth, H. D. 1998. Dasar - Dasar Ilmu Tanah. Edisi ke Tujuh. Gadjah Mada University Press.

Hanafiah, K. A. 2005. Dasar - Dasar Ilmu Tanah. Divisi Buku Perguruan Tinggi PT. Raja Grafindo Persada. Jakarta.

Hardjowigeno, S. 2003. Klasifikasi Tanah dan Pedogenesis. Jakarta : Akademika Pressindo.

Pairunan A.K., J.L. Nanere, Arifin, Tangkaisari R, Solo S.R Samosir, Bachrul Ibrahim, Hariadji Asmadi., 1985. Dasar-Dasar Ilmu Tanah. Badan Kerja Sama Perguruan Tinggi Negeri Indonesia Timur, Makassar.

Subagyo, H. N. Suharta, dan A. B. Siswanto. 2004. Tanah - Tanah Pertanian di Indonesia. 21 - 66 hal. 